\title{
A new species of Tigriopus (Copepoda, Harpacticoida, Harpacticidae) from Thailand with the description of its naupliar development
}

\author{
Supawadee Chullasorn - Viatcheslav N. Ivanenko • \\ Hans-U Dahms · Pawana Kangtia $\cdot$ Wan-Xi Yang
}

Received: 11 December 2008/Revised: 19 February 2011/Accepted: 16 March 2011/Published online: 5 April 2011

(C) Springer-Verlag and AWI 2011

\begin{abstract}
Both genders of Tigriopus thailandensis sp. nov. are described from a laboratory stock raised from individuals collected from the seaweed Enteromorpha clathrata in Thailand (Bangsaen Beach, Chonburi Province). Tigriopus thailandensis sp. nov. shares with its closest relative T. japonicus Mori, 1932 two setae on the third exopodal segment of leg 4 while other congeners bear 3 inner setae. However, allobasis and exopod of antenna in both genders are much more slender and elongate than in T. japonicus. All six naupliar stages of T. thailandensis are described from the offspring of isolated females. In comparison with nauplii of $T$. japonicus, T. thailandensis nauplii are characterized by the following: a smaller body size throughout the naupliar phase; first antennular segment without seta, second antennular segment with only one small seta plus two longer setae; third antennular segment
\end{abstract}

Communicated by Peter Funch.

S. Chullasorn · P. Kangtia

Faculty of Science, Ramkhamhaeng University,

Bangkok 10240, Thailand

\section{N. Ivanenko}

Department of Invertebrate Zoology, Biological Faculty,

Moscow State University, Moscow 119899, Russia

H.-U. Dahms ( $\square)$

Green Life Science Department, College of Natural Science,

Sangmyung University, 7 Hongij-dong, Jongno-gu,

Seoul 110-743, South Korea

e-mail: hansdahms@smu.ac.kr

W.-X. Yang $(\bowtie)$

The Sperm Laboratory, College of Life Sciences,

Zhejiang University, Zi Jin Gang Campus,

310058 Hangzhou, Zhejiang, China

e-mail: wxyang@spermlab.org with additional spinules from naupliar stage II onwards; antenna bears three small spinules on the terminal exopodal segment; one additional seta on the anterior surface of the antennary basis, tubular endopod of antenna with one tiny seta midlength at naupliar stage III that increases in size; mandibular basis with several spinules on anterior surface; mandibular coxa with one spinulose seta that is smooth in T. japonicus.

Keywords Zoosystematics - Species description . External morphology · Naupliar development . Larval stages · Evolution - Harpacticidae · Thailand
Abbreviations
Enp (Exp) I
First segment of endopod (exopod)
$1-4+$ Ae
Example of antennular/antennary armature corresponding to 1 seta on first and 4 setae plus 1 aesthetasc on second segment
N I and N VI Naupliar stages I and VI, respectively

\section{Introduction}

The worldwide distributed genus Tigriopus Norman, 1869, consists of 11 valid species (Wells 2007) that are characterized by their high resistance to changes in temperature, salinity, and oxygen and inhabit supralittoral rockpools (see McAllen and Block 1997; McAllen et al. 1998; McAllen 1998, 1999). Copepods of the genus Tigriopus became a focal point of several in-depth studies, e.g., its ecotoxicology reviewed by Raisuddin et al. (2007), its field ecology (Dethier 1980), life history (Koga 1970), external and internal anatomy (Itô 1973; Dahms et al. 2007), chemical 


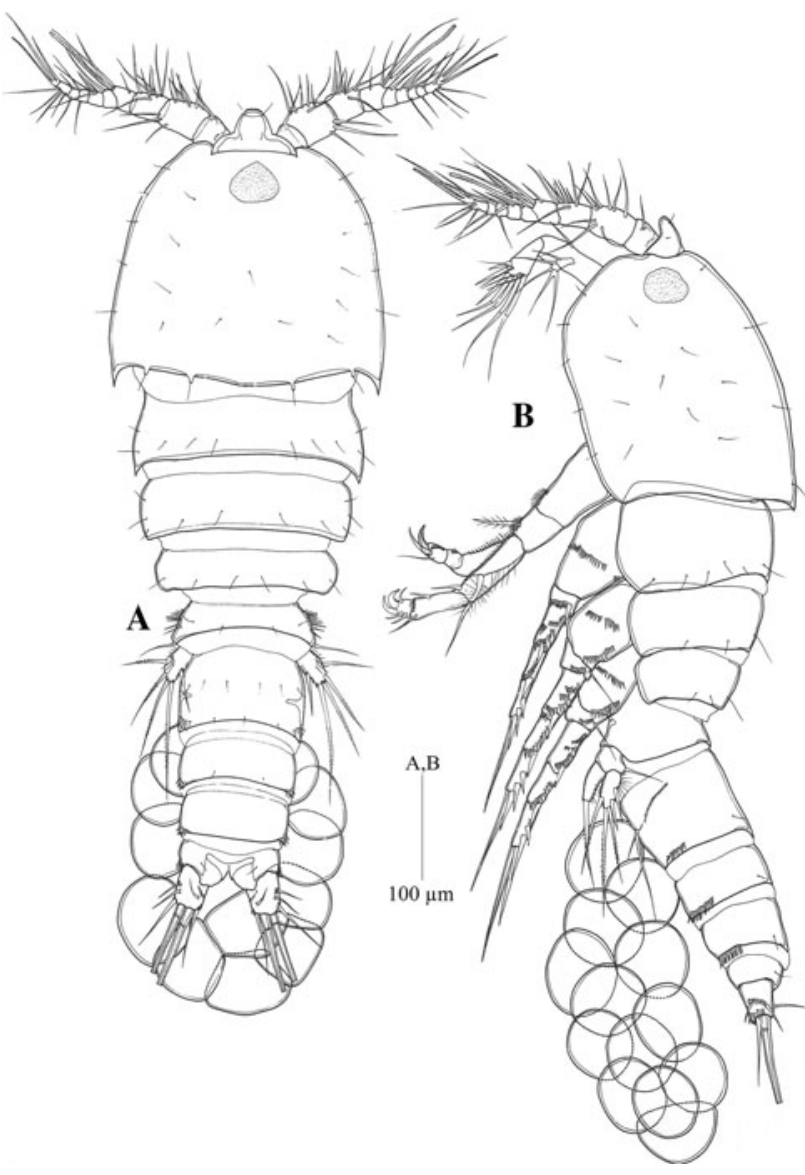

Fig. 1 Tigriopus thailandensis sp. nov. Female. a, habitus, dorsal view; b, habitus, lateral view

ecology (Kelly and Snell 1998), and genetics of adaptation (Davenport et al. 1997; Burton et al. 1999). Other areas of research are represented by genomics in general (Machida et al. 2002; Kim et al. 2003; Lee 2003; Lee et al. 2005; Jung et al. 2006), medicine-related genetics (Kim et al. 2004), and the genetics of populations (Edmands and Burton 1998; Edmands 1999). The life cycles of Tigriopus spp. have been studied by Guiglia (1926), Fraser (1936), and Shaw (1938). Nauplii of T. fulvus have been described by Igarashi (1963), and nauplii of $T$. japonicus Mori 1932 were described by Dahms et al. (2007).

Nauplii can play significant ecological roles due to their abundances and variety (Alekseev 2002). However, lifehistory studies in the field and investigations into stagespecific phenomena in the laboratory are hampered by the lack of descriptive information as well as keys for identification (Dahms 1993; Dahms et al. 2006; Ivanenko et al. 2008). Much rearing and descriptive work has to precede any attempt to tackle ontogeny-related problems. Although there are some naupliar studies dealing with the postembryonic development of Tigriopus (Igarashi 1963; Itô 1970; Dahms 1990, 1993), an update is provided with the present

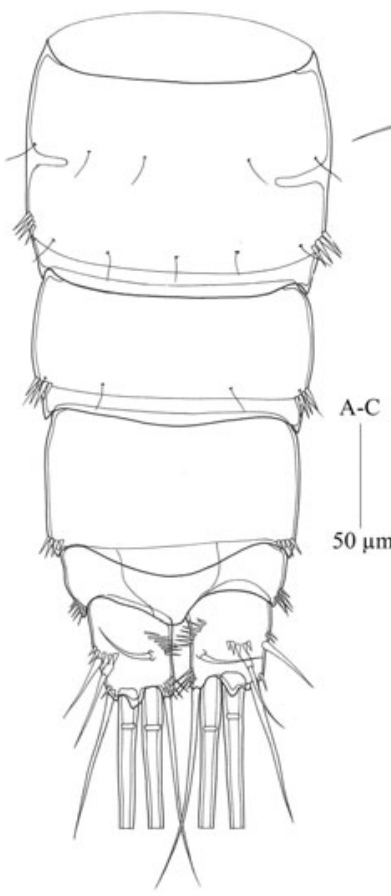

A

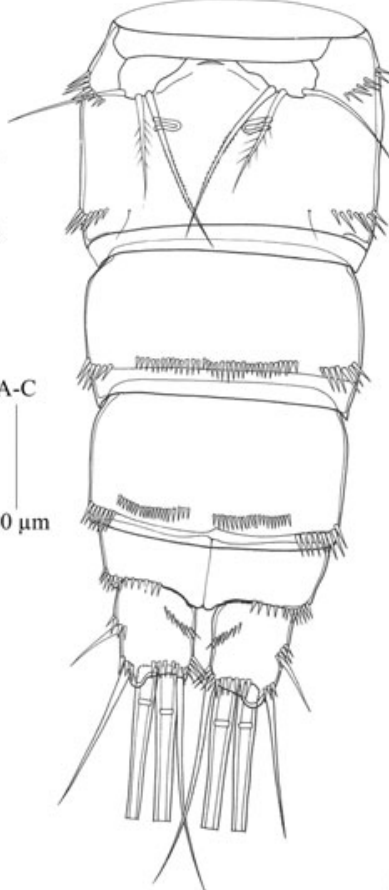

B

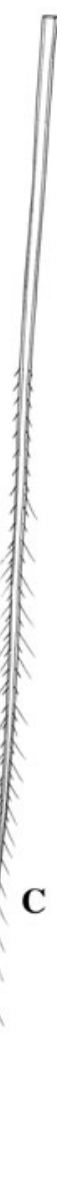

Fig. 2 Tigriopus thailandensis sp. nov. Female. a, urosome, dorsal view; $\mathbf{b}$, urosome, ventral view. c, terminal seta of caudal ramus

new species described here. Here, we provide a morphological description of adults of both genders and the nauplii of Tigriopus thailandensis sp. nov.

\section{Materials and methods}

Adults of T. thailandensis sp. nov. were collected during low-tide at sandy Bangsaen Beach, Chonburi Province, Thailand $\left(13^{\circ} 19^{\prime} \mathrm{N}, 100^{\circ} 54^{\prime} \mathrm{E}\right)$. Different developmental stages of $T$. thailandensis, including ovigerous females, were washed out from thalli of the alga Enteromorpha clathrata. The residue containing ovigerous females was subsequently decanted over a $50-\mu \mathrm{m}$ mesh screen. Adults were rinsed into smaller bowls for transport to the laboratory. Cultivation was carried out in glass dishes as described in detail by Dahms et al. (2007).

Specimens were washed in filtered seawater and fixed in $4 \%$ seawater-formaldehyde. The stages were subsequently embedded in glycerol. Body measurements of nauplii were taken from the frontal portion of the naupliar shield to the caudalmost protrusion of the hindbody (length) and the 


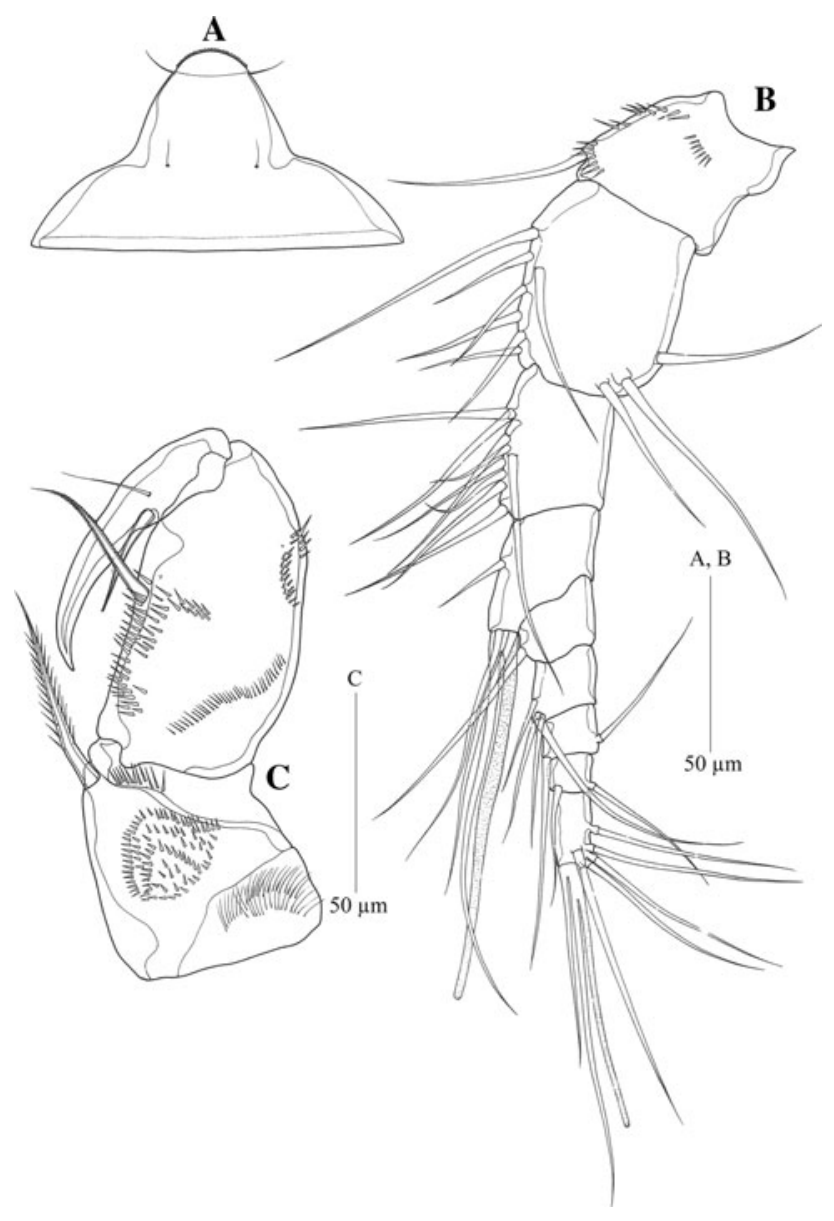

Fig. 3 Tigriopus thailandensis sp. nov. Female. a, rostrum, dorsal view; b, left first antennule; c, maxilliped; $\mathbf{b}$ and $\mathbf{c}$ - anterior view

widest lateral tips of the naupliar shield (width); only specimens drawn were considered for length measurements. Two to five specimens per stage were used for the investigation of stage-specific variability. The developmental stages used in the present study represent the offspring of exclusively single-female cultures. Other details and descriptive terminology of nauplii follow Dahms et al. (2007).

Type material The type material has been deposited in the National Museum of Natural History, Smithsonian Institution, Washington, D.C.: the dissected female holotype (USNM 1115488), the dissected male allotype (USNM 1115489), 1 female paratype (USNM 1115490), and 1 male paratype (USNM 1115491). The type material was collected on December 23, 2006, in Chonburi Province, Thailand.

\section{Descriptive part}

Order Harpacticoida Sars, 1903

Suborder Oligoarthra Lang, 1944

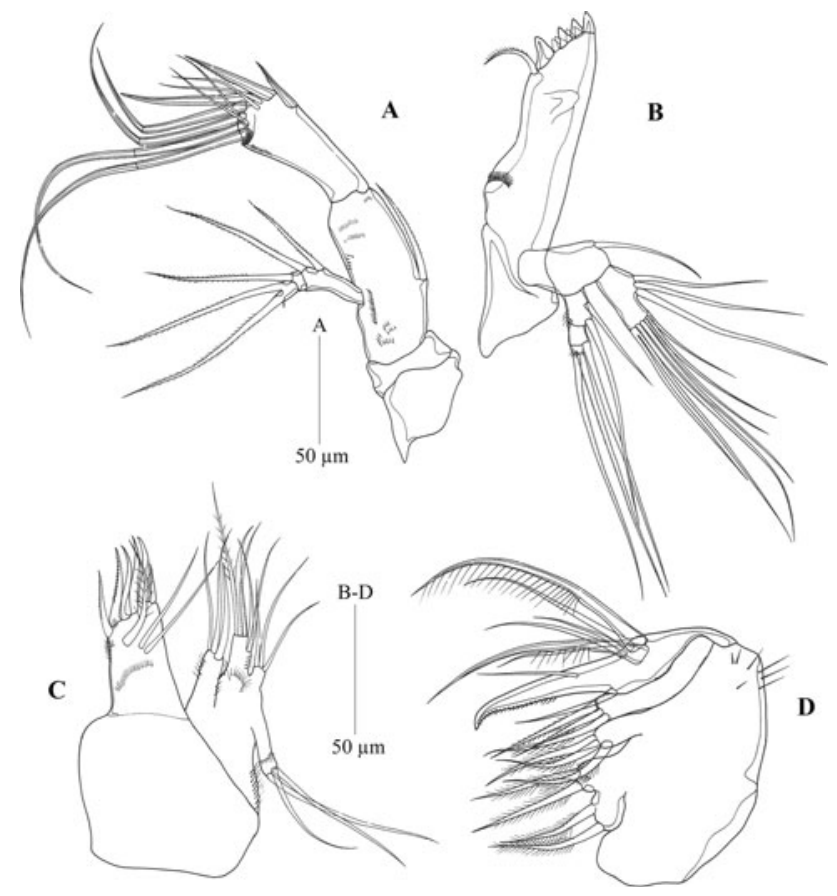

Fig. 4 Tigriopus thailandensis sp. nov. Female. a, left antenna; b, mandible; c, first maxilla; d, second maxilla; $\mathbf{b}-\mathbf{d}-$ posterior view

Family Harpacticidae Dana, 1846

Genus Tigriopus Norman, 1869

Tigriopus thailandensis sp. nov.

Etymology The species name refers to the country where this new species was found.

Distribution Tigriopus thailandensis sp. nov. was associated with a green alga, Enteromorpha clathrata attached to an old big plastic bag collected during low-tide at Bang Saen sandy beach in Chonburi Province, Thailand $\left(13^{\circ} 19^{\prime} \mathrm{N}, 100^{\circ} 54^{\prime} \mathrm{E}\right)$.

\section{Adult female and male}

Female (Figs. 1, 2, 3, 4, 5, 6)

Total length of holotype female $0.93 \mathrm{~mm}$; paratype, total length $0.98 \mathrm{~mm}$, measured from tip of rostrum to posterior margin of caudal ramus. Body (Fig. 1a, b) orange in color, compact, ornamented with sensillae. Cephalosome as long as succeeding separate 4 somites of prosome combined, with well-developed rostrum; cephalothorax and first pedigerous somite separate (Fig. 1a, b). Urosome (Fig. 2a, b) slightly tapering posteriorly. Rostrum (Fig. 3a) as long as first segment of antennule, rounded at tip, and with a pair of sensilla at the tip. Labrum prominent, with 4 spiniform processes and many hairs at the apical edge. Genital double 


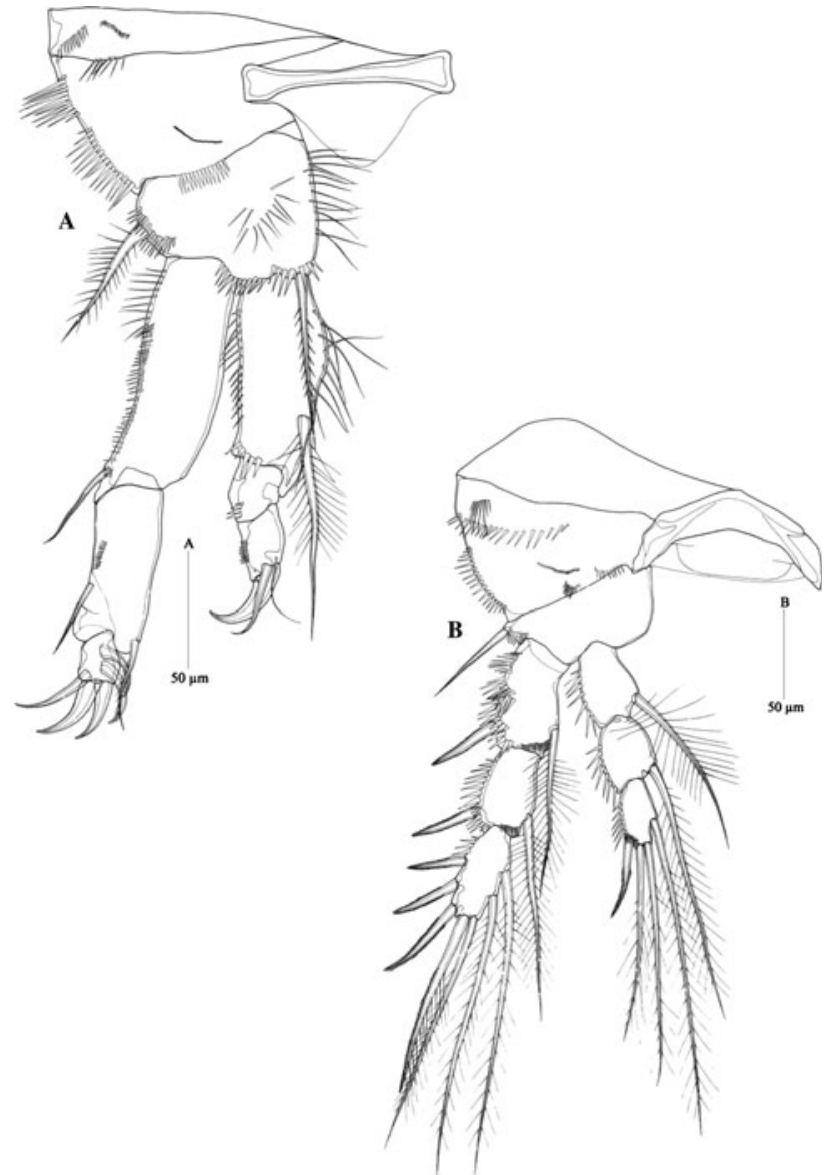

Fig. 5 Tigriopus thailandensis sp. nov. Female. a, right leg 1; b, right leg 2. Posterior view

somite (Fig. 2b) with 2 oblique spinular rows on the outer and inner corner on ventral surface.

Urosome (Fig. 2a, b) 6-segmented, comprising P5bearing somite and 3 abdominal somites ornamented with short oblique rows of spinules on distal corner dorsally and ventrally of each somite. Second urosomite furnished with more sensillae in dorsal view. Genital double-somite with leg 6, genital field indistinct with 2 small copulatory apertures ventrally. Third to fifth urosomal somites ornamented with 1 row of minute spinules along posterior margin. Caudal ramus as wide as long, principal terminal caudal seta longer than length of urosome (Fig. 2c).

Antennule (Fig. 3b) 9-segmented. Second segment largest. Fourth and terminal segment with 1 large and 1 small aesthetasc, respectively. Length of two proximal segments as that of five apical segments combined. Armature formula: $1-10-9-4+$ Ae. $-1-4-2-2-$ $7+$ Ae.

Antenna (Fig. 4a): pre-antennary sclerite and coxa bare. Endopod 2-segmented: first segment of allobasis with 1 seta on middle of anterior edge and furnished with rows of minute spinules on the surface; second segment endopod

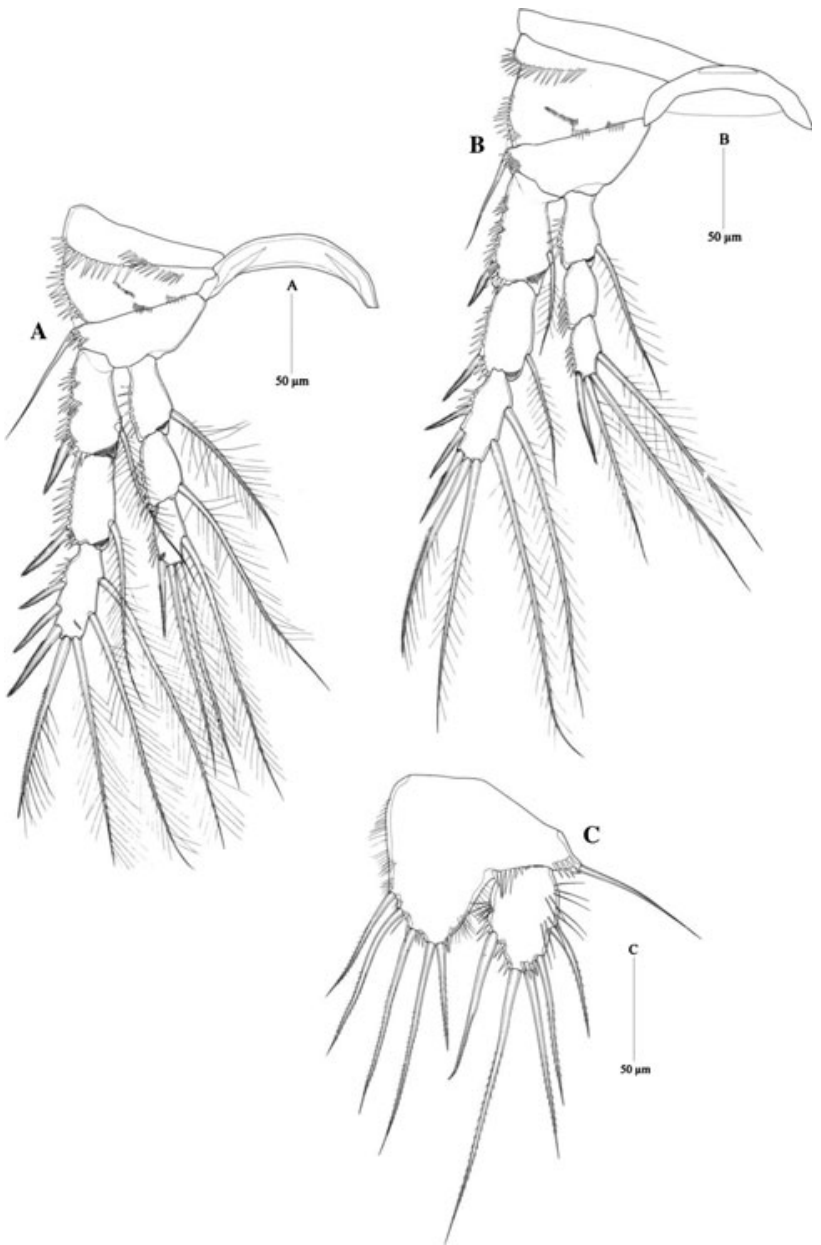

Fig. 6 Tigriopus thailandensis sp. nov. Female. a, right leg 3; b, right leg 4; c, left leg 5. Posterior view

with 4 long setae at base, 4 short and slender setae, and 3 short spines. Exopod 3-segmented: first segment longest with 2 setae, second segment shorter with 1 seta, third segment with 1 lateral and 1 terminal seta.

Mandible (Fig. 4b): coxa well developed with 1 arched spinular row at midlength. Cutting edge with 4 strong and 4 small spines, and 1 spinulose seta; basis with 1 apical seta; exopod 3-segmented: first segment with 2 setae and few spinules, second segment with 1 seta, third segment with 2 setae and minute spinules; endopod 1-segmented with 3 setae at middle inner edge, and 7 setae on distal end.

Maxillule (Fig. 4c): arthrite of praecoxa with 2 slender and 1 plumose setae on surface, 4 bare and 2 pinnate spines on inner edge. Coxa with 3 setae on inner end; basis spinulated on outer face; 1 slender spine and 2 setae at distal end; 2 subdistal setae, 2 of which juxtaposed; exopod with 3 setae and some spinules near distal end; endopod small, with 3 terminal setae.

Maxilla (Fig. 4d): syncoxa with 3 endites; proximal endite bilobular, each lobule with 2 plumose setae on distal 


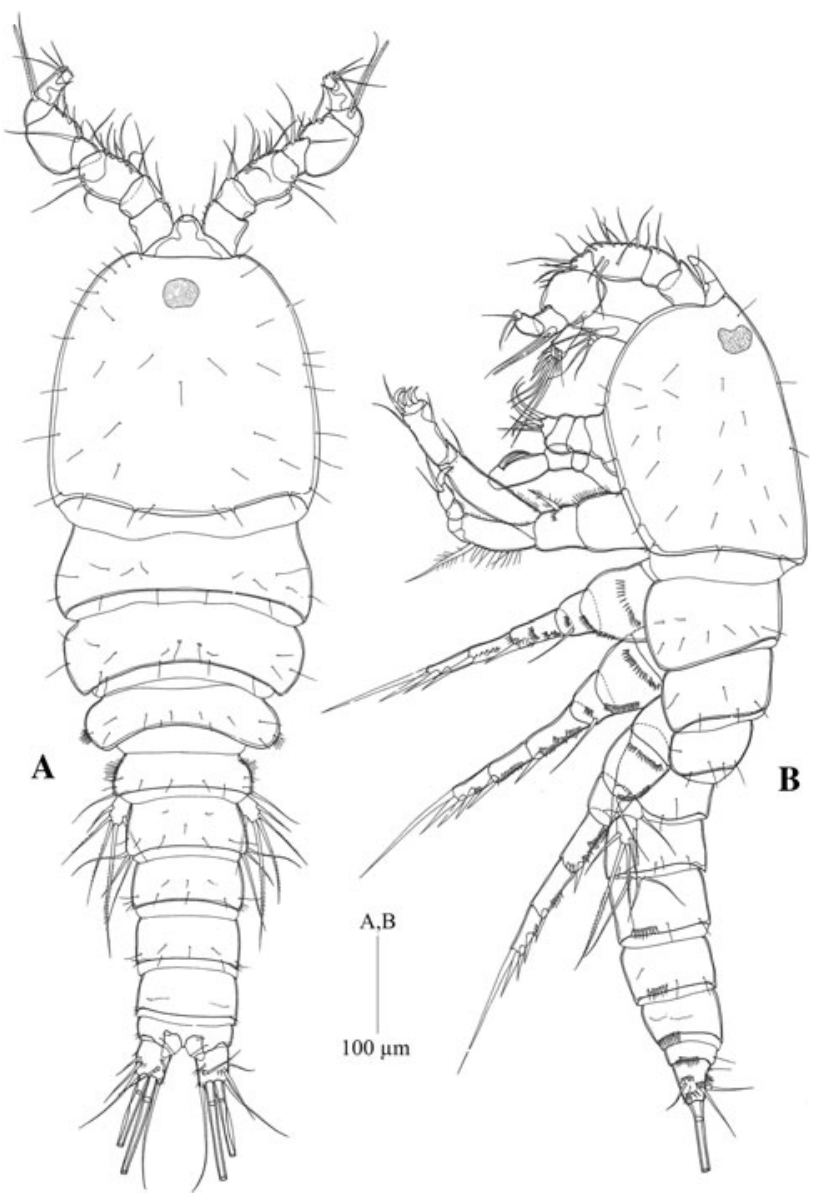

Fig. 7 Tigriopus thailandensis sp. nov. Male. a, habitus, dorsal view; b, habitus, lateral view

end, and distal one with a spinular row transversely; each other endite with 3 plumose setae on distal end; basis furnished with a strong claw that is pectinate along distal part of inner edge; 2 strong, remarkably plumose setae and 5 slender bare setae near base of claw.

Maxilliped (Fig. 3c): syncoxa and basis well developed with outer row of spinules midlength; basis small with a subdistal row of spinules. Endopod 2-segmented: first segment well developed with slightly undulating inner margin, 2 perpendicular spinule rows on outer edge and 2 short rows of slender spinules at inner border; second segment with 2 small outer setae, ornamented with denticuliform spinules at inner border. Enp II and its claw together nearly as long as basis.

Leg 1 (Fig. 5a): praecoxa and coxa with a particular spinular ornamentation pattern as shown in the drawing; basis with a spiniform seta on the inner and one on the outer distal corner; endopod much shorter than exopod, both 3-segmented. Enp I distinctly longer than enp II and enp III, with 1 long and strong spine-like seta at outer distal corner; enp II as long as terminal segment without seta; enp III with 1 big outwardly curved claw-like spinulose seta,

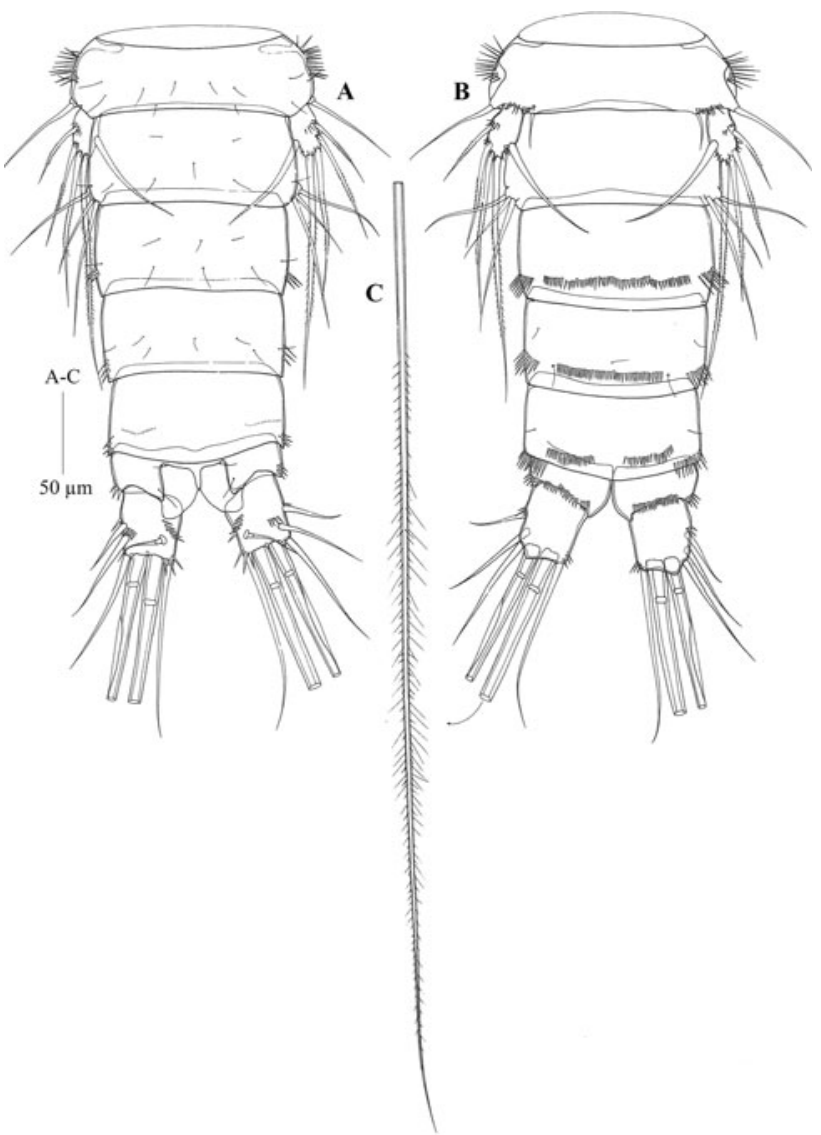

Fig. 8 Tigriopus thailandensis sp. nov. Male. a, urosome, dorsal view; $\mathbf{b}$, urosome, ventral view. c, terminal seta of caudal ramus

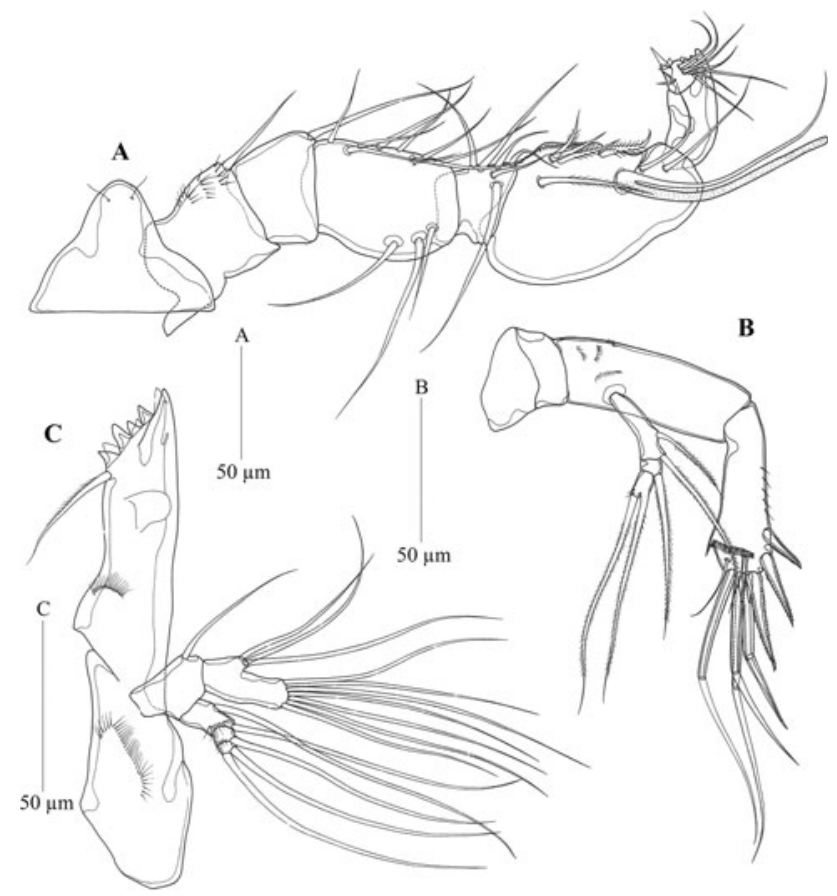

Fig. 9 Tigriopus thailandensis sp. nov. Male. a, rostrum and right antennule, dorsal view; b, right second antenna, anterior view; c, mandible, posterior view 
Fig. 10 Tigriopus thailandensis sp. nov. Male. a, maxillule; b, maxilla; c, maxilliped. Posterior view

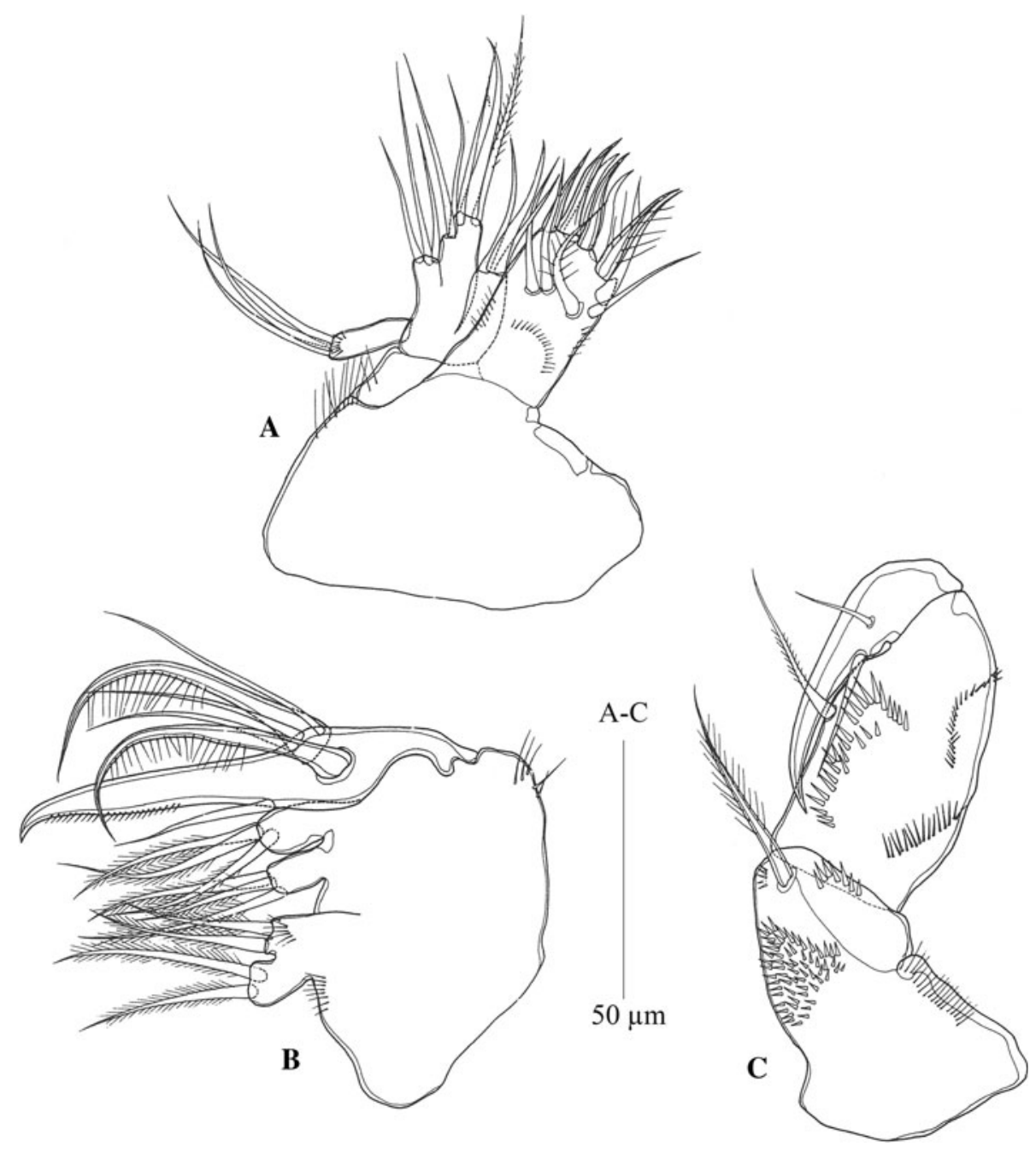

1 spine-like and 1 slender inner seta. Both exp I and exp II elongated, exp III very small. Exp I with 1 pinnate seta on distal outer corner; exp II with 1 pinnate seta at two-thirds of outer margin, and 1 spinulose seta on inner distal corner; exp III with 2 median distal claw-like setae, 1 outer and 2 inner spine-like setae.

Legs 2-3 (Figs. 5b, 6a): basis with 1 pinnate seta on outer corner. Endopod 3-segmented; enp I and enp II each with 1 inner plumose seta; enp III with 1 outer pinnate spine-like seta, 3 plumose setae: 2 median distal and 1 outer. Exopod 3-segmented; exp I and exp II each with 1 outer pinnate spine, and 1 inner plumose seta; exp III with 3 outer pinnate spines, 2 plumose setae apically, and 2 inner plumose setae.

Leg 4 (Fig. 6b): as leg 2 and leg 3, except enp II without inner seta.

Leg 5 (Fig. 6c): baseoendopod large, furnished with rows of spinules, with 1 outer basal seta and 5 spinulose setae of unequal length on endopodal lobe, the second outermost longest. Exopod 1-segmented, anterior face covered with longer-sized spinules, with 5 spinulose setae of unequal length, the second innermost longest.

Male (Figs. 7, 8, 9, 10, 11, 12)

Total length of holotype male $0.94 \mathrm{~mm}$; paratype, total length $1.0 \mathrm{~mm}$, measured from tip of rostrum to posterior margin of caudal ramus. Male morphology as in female except the following characters. Antennule (Fig. 9a) subchirocer, 8-segmented: first segment with small spinules on anterior inner surface, fifth one shortest, sixth one globularly expanded with a big aesthetasc, seventh one forming a claw-like outer process, and last one small. Armature formula: 1-1-11-3-2-8 + Ae.-0-9. Antenna (Fig. 9b): anterior edge of allobasis without seta, all other armature as in female.

Leg 2 (Fig. 11b): Basis with 1 pinnate outer seta. Endopod 3-segmented: first segment with 1 inner seta; 


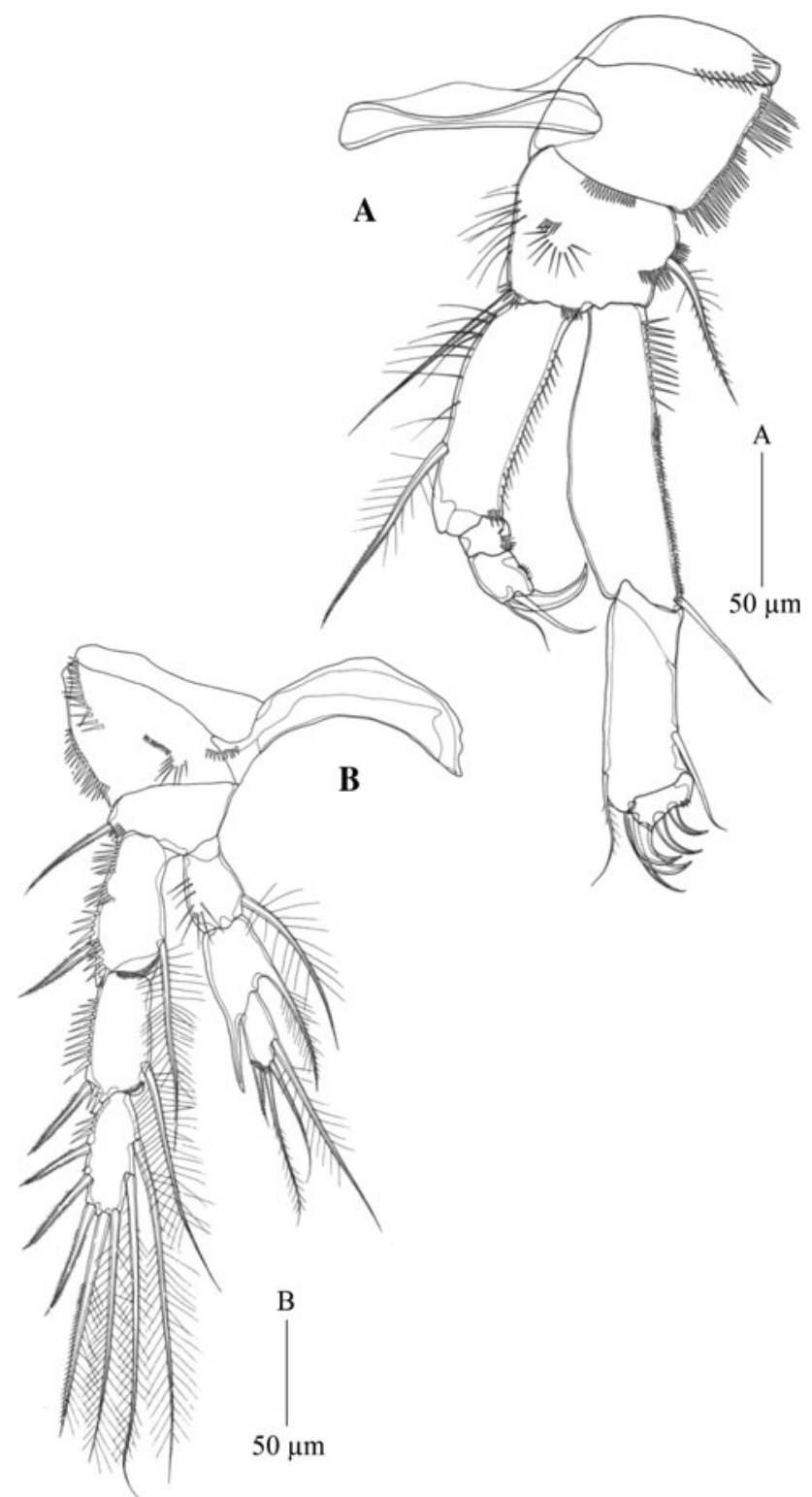

Fig. 11 Tigriopus thailandensis sp. nov. Male. a, right leg 1; b, right leg 2; Posterior view

second segment with 1 inner spinulose seta, comparatively short, and 1 plumose spinous process at outer distal corner; third segment small, not reaching to third exopodal segment, with 3 setae distally: 1 bare, 1 plumose, 1 pinnate, and 1 longer plumose seta at inner edge. Exopod 3-segmented, armed as in female. Leg 5 (Fig. 12c): baseoendopod small, with 1 inner short endopodal seta, and 1 long slender outer seta. Exopod about 1.5 times as long as wide, with 1 bare inner, 2 spinulose apical, and 2 outer spinulose setae; apical, innermost seta longest, about 5 times as long as exopod. Leg 6 (Fig. 8a, b) represented by 3 setae, innermost 1 longest and middle 1 shortest (Table 1).

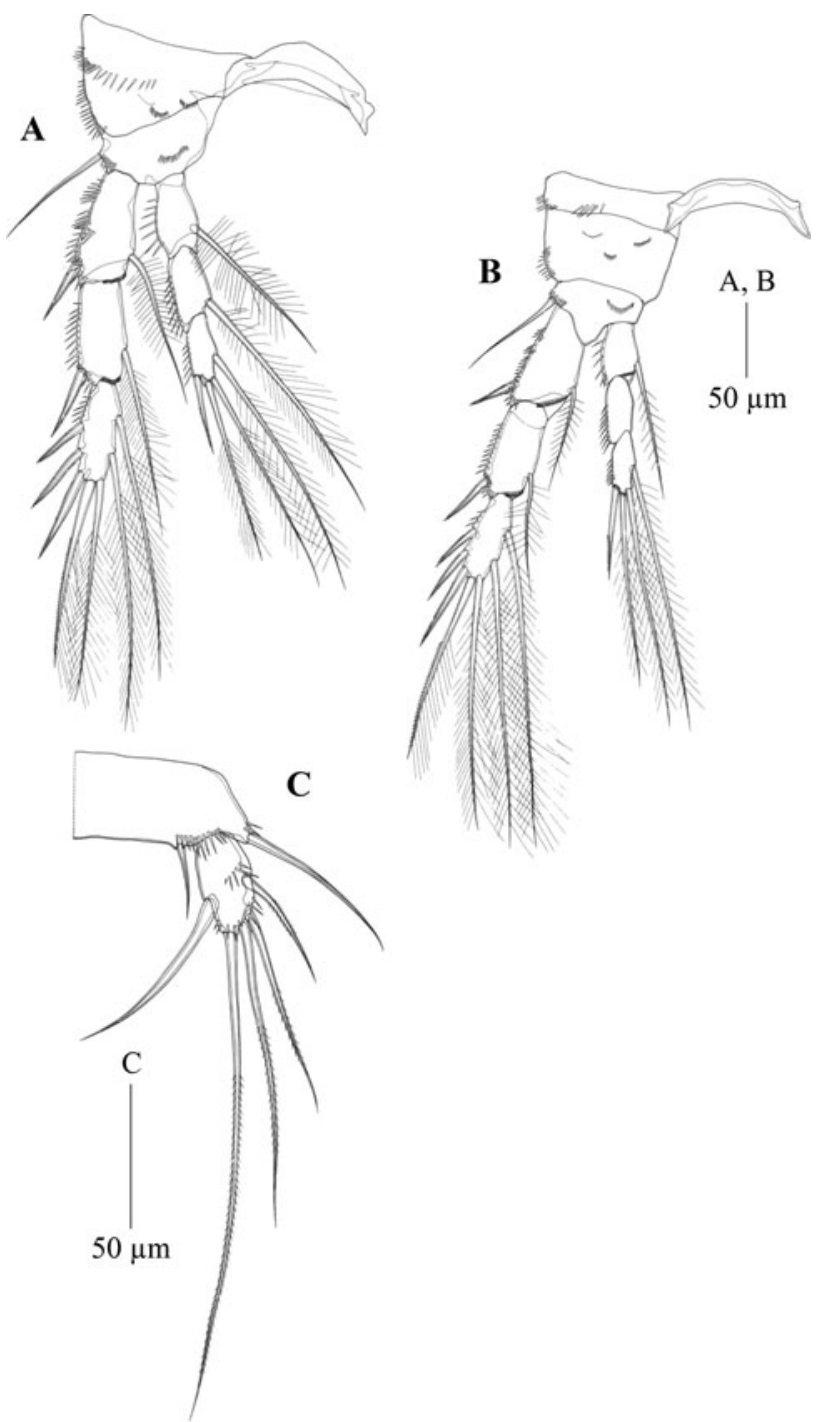

Fig. 12 Tigriopus thailandensis sp. nov. Male. a, right leg 3; b, right leg 4; c, left leg 5. Posterior view

Table 1 Armature formulae of legs 1-4 of Tigriopus thailandensis sp. nov

\begin{tabular}{|c|c|c|}
\hline & Exp & Enp \\
\hline P1 & $\begin{array}{lll}0 & 1 & 2: 2: 1\end{array}$ & 10 1:2:0 \\
\hline $\mathrm{P} 2$ & $112: 2: 3$ & $\begin{array}{lll} & 1 & 1: 2: 1\end{array}$ \\
\hline $\mathrm{P} 3$ & $112: 2: 3$ & 11 1:2:1 \\
\hline P4 & $112: 2: 3$ & $\begin{array}{lll}10 & 0 & 1: 2: 1\end{array}$ \\
\hline
\end{tabular}

Naupliar stages I-VI (Figs. 13, 14, 15, 16, 17, $18,19,20,21)$

Nauplius I (Figs. 13, 17, 18, 20)

Body length $116 \mu \mathrm{m}$, body width $103 \mu \mathrm{m}$. Body reddish with a dark median eye, slightly longer than wide and 


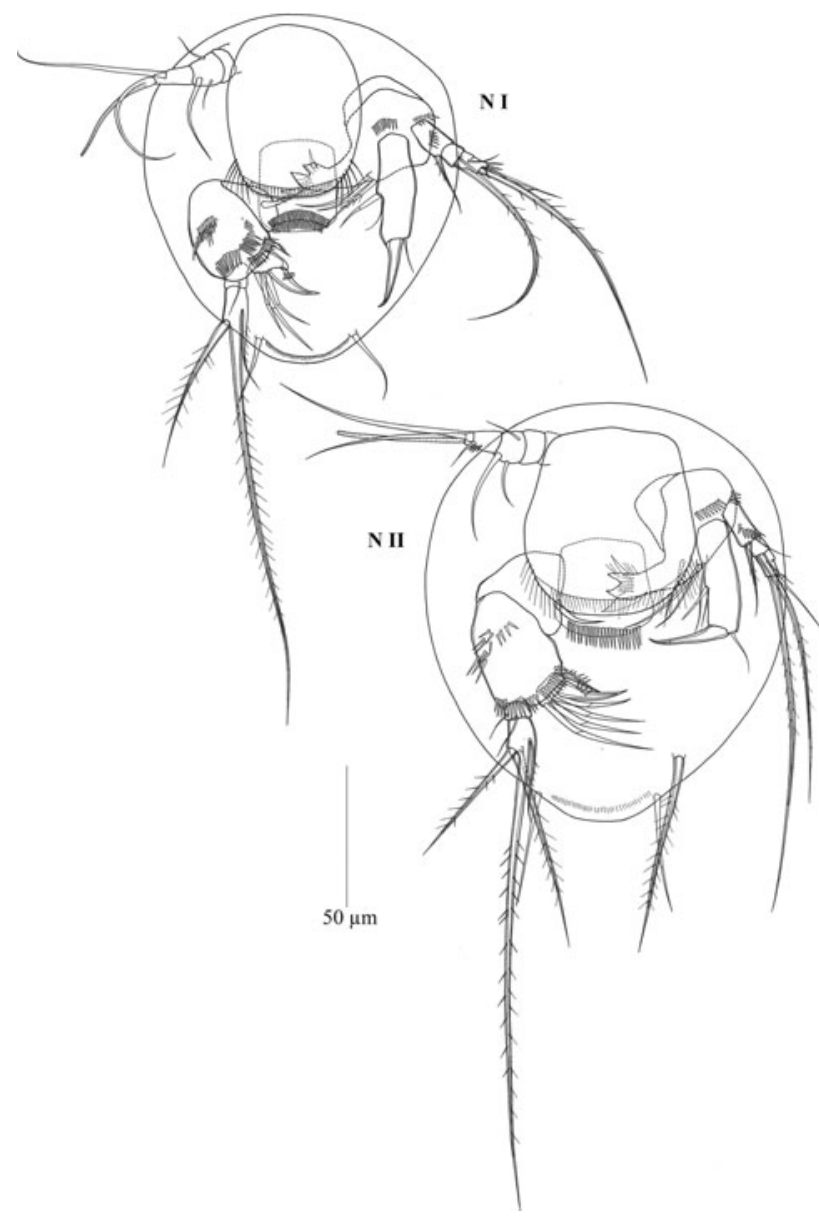

Fig. 13 Tigriopus thailandensis sp. nov. Naupliar stages I and II in ventral view. Abbreviations: N I and N II-naupliar stages I and II, respectively

cephalic shield showing lobular bulges on both lateral sides. Rectangular labrum furnished with hairy spinules along the distal posterior edge and longer spinules on lateral corners. Sternal field ornamented with 2 rostrally curved rows of spinules in between insertions of antennae. Hindbody bears 1 seta (=the initial furca), arising from a protuberance on each caudal side and a curved row of minute spinules in between (Fig. 13).

Antennule 3-segmented (Fig. 17): first segment without seta; second segment with 2 small setae near middle and 1 large seta at inner margin; distal segment armed with 2 setae and 1 aesthetasc.

Antenna (Fig. 18) bears an unornamented ring-shaped coxa. Basis large and medially drawn out into a bifurcated pincer-like masticatory process, armed distally with tiny spinules, 1 inner seta and 1 outer flap, and pointing under labrum toward mouth. Basal endite bearing 2 smooth setae and 1 plumose seta on anterior surface; 2 short rows of spinules, 1 in the middle and 1 row at the outer corner. Cylindrical endopod 1-segmented, about 3 times as long as first exopodal segment, with 2 subequal median inner setae

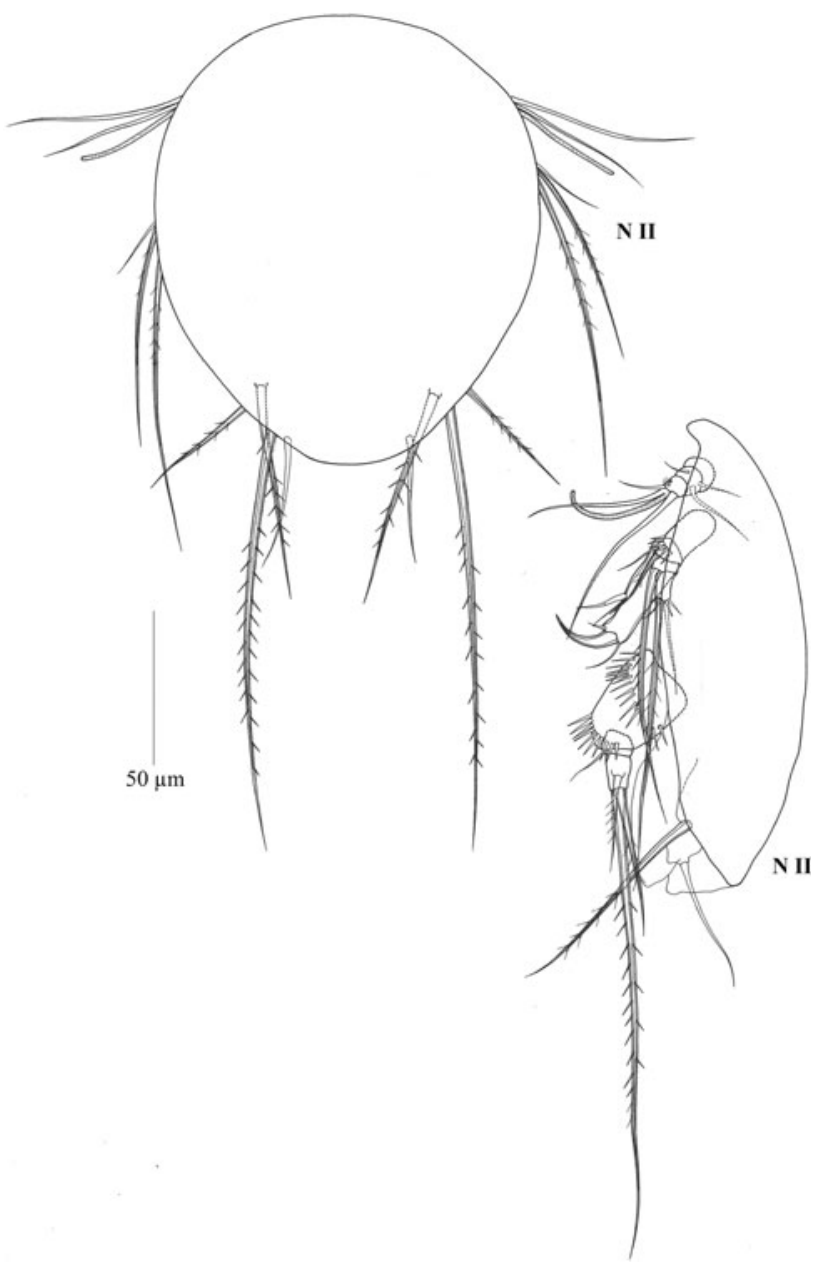

Fig. 14 Tigriopus thailandensis sp. nov. Naupliar stage II in dorsal and lateral view

and 1 short terminal seta, and 1 large claw-shaped seta distally. Exopod 3-segmented: first segment bears 1 spinulose seta at inner corner. Second segment shorter, bearing 1 long spinulose seta. Third segment with 1 smooth seta and 1 longer spinulose terminal seta, and 3 spinules on outer corner plus 1 very slender seta.

Mandible (Fig. 20) with a short proximal portion (=initial coxa) with 1 spinulose seta. Anterior surface of large basis furnished with many transverse rows of slender spinules medially and at inner protrusion. Basal endite furnished on an elongate claw-shaped spine with 4 small spinules midlength and 3 long smooth setae. Exopod 2-segmented: first segment with 1 terminal smooth seta; second segment bearing 1 smaller spinulose inner seta, 1 outer large spinulose seta, and 1 long attenuated spinulose seta.

Nauplius II (Figs. 13, 14, 17, 18, 20)

Body length $139 \mu \mathrm{m}$, body width $119 \mu \mathrm{m}$. N II differs from $\mathrm{N}$ I in the following aspects. Sternal field ornamented with only 1 row of slender spinules in between insertions of 


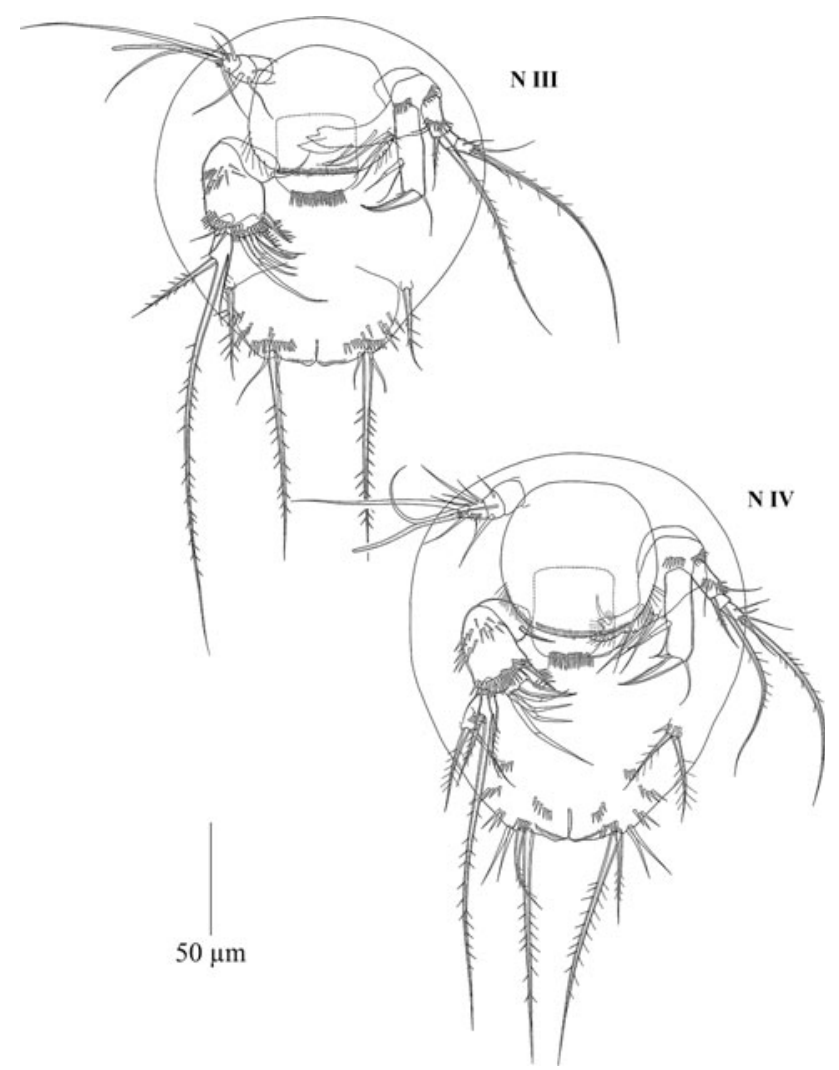

Fig. 15 Tigriopus thailandensis sp. nov. Naupliar stages III and IV in ventral view. Abbreviations: N III and N IV -naupliar stages III and IV, respectively

antennae. Hindbody with 1 additional seta on either side (Figs. 13, 14). Antennule (Fig. 17) with 1 additional median seta and 5 small setae at anterior inner margin on its distal segment. Antenna (Fig. 18): basal endite bearing 1 additional seta. Tubular endopod bearing 1 small spine at distal margin. First segment of exopod ornamented with 1 oblique row of 7 spinules. Mandibular coxal spinulose seta became smooth seta (Fig. 20). Basal endopod bearing 1 additional seta. One additional seta at outer corner of the first segment of exopod. Maxillule represented by a spinulose seta.

\section{Nauplius III (Figs. 15, 17, 18, 20)}

Body length $150 \mu \mathrm{m}$, body width $143 \mu \mathrm{m}$. N III differs from N II in the following aspects. Hindbody with 1 additional seta on either side (Fig. 15). Antennule (Fig. 17) with 4 additional setae on anterior surface of its distal segment. Antenna (Fig. 18): gnathobase bearing 1 spinule at midlength of masticatory process. Cylindrical endopod of antenna bears a tiny spinule at midlength close to the former larger spine. Large claw-shaped seta of tubular endopod armed with tiny spinules along inner side. Exopod

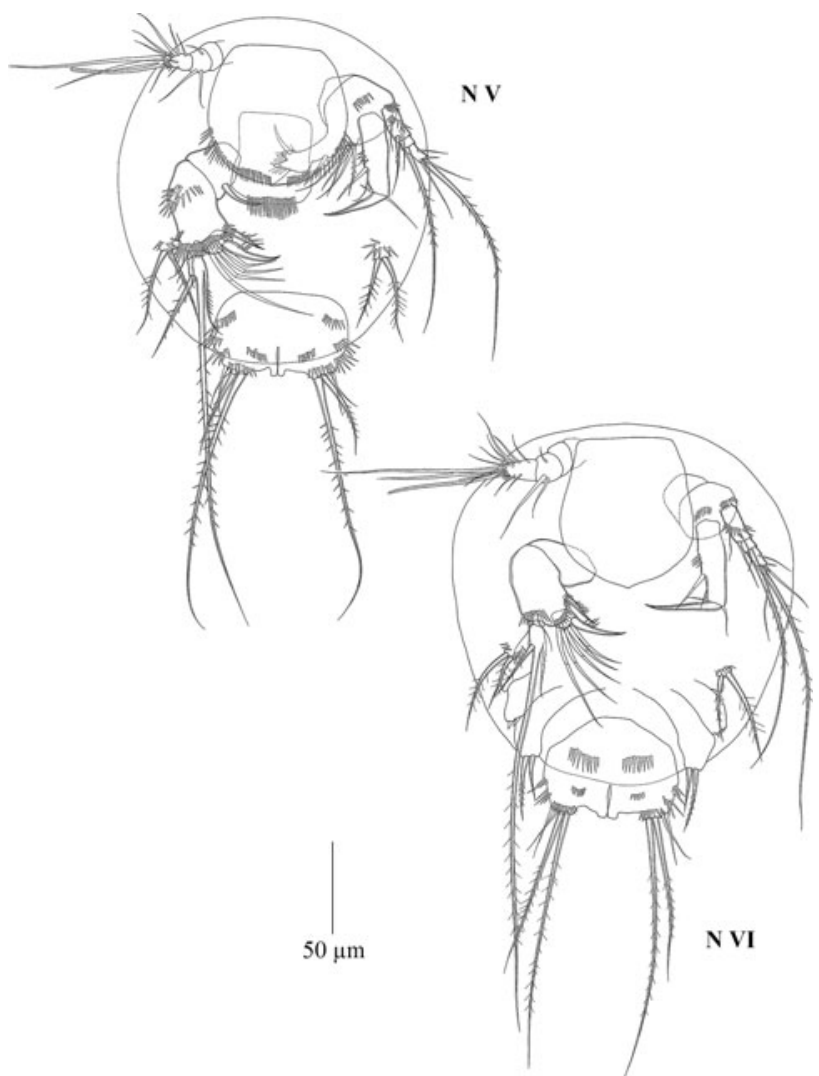

Fig. 16 Tigriopus thailandensis sp. nov. Naupliar stages V and VI in ventral view. Abbreviations: N V and N VI-naupliar stages V and VI, respectively

without clear changes to that of N II. Mandibular basis bearing 1 additional long seta (Fig. 20).

Nauplius IV (Figs. 15, 17, 18, 21)

Body length $168 \mu \mathrm{m}$, body width $145 \mu \mathrm{m}$. N IV differs from N III in the following aspects. Hindbody with 1 additional seta on either side (Fig. 15). Antennule (Fig. 17) on its distal third segment with 1 additional slender seta on anterior face and 3 small setae on posterior face. Antenna's former tiny spinule on cylindrical endopod became longer (Fig. 18). Distal segment bearing 1 terminal spinule. Mandibular basis and exopod without change to that of $\mathrm{N}$ III (Fig. 21). Maxillule with 1 additional slender seta (Fig. 15).

Nauplius V (Figs. 16, 17, 19, 21)

Body length $191 \mu \mathrm{m}$, body width $166 \mu \mathrm{m}$. N V differs from N IV in the following aspects. Hindbody showing 4 setae in total as at stage IV, 2 subequal spinulose setae and 2 subequal smooth setae on each side, and bearing an abdominal bud (Fig. 16). Cylindrical endopod of second 


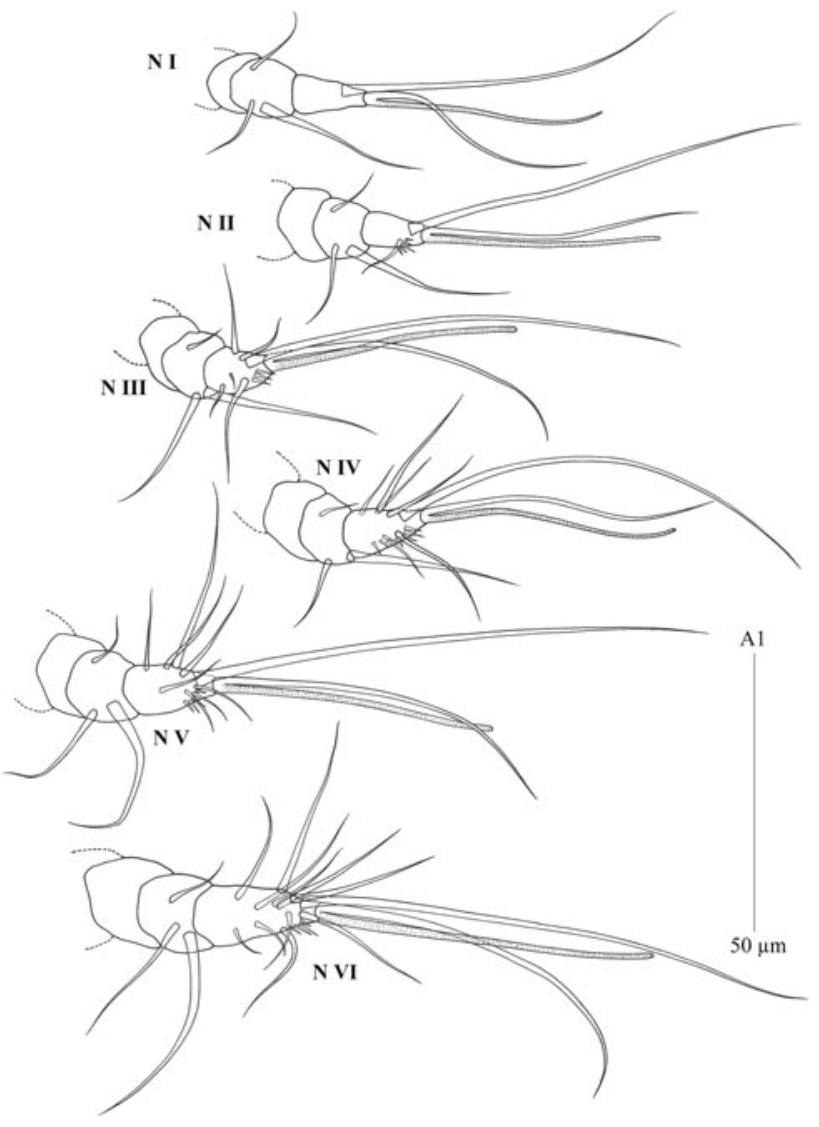

Fig. 17 Tigriopus thailandensis sp. nov. Development of the naupliar left antennule of naupliar stages I to VI in anterior view. Antennule of first to sixth naupliar stage abbreviated as N I to N VI, respectively

antenna bearing 4 spinules at midlength along inner margin of its segment (Fig. 19). Claw-shaped seta of mandibular endopod ornamented with 5 spinules at proximal inner margin (Fig. 21).

\section{Nauplius VI (Figs. 16, 17, 19, 21)}

Body length $203 \mu \mathrm{m}$, body width $176 \mu \mathrm{m}$. N VI differs from $\mathrm{N} \mathrm{V}$ in the following aspects. The labrum without spinules along its edge. Sternal field without row of spinules in between insertions of antennae. Antenna without basipodal endite and gnathobase; distal segment of exopod with additional seta (Fig. 19). Mandibular coxa without any seta, endopod expanded (Fig. 21). Inner edge with enditic lobes; 1 seta on endopod, 1 seta on prospective exopod. With 4 lobular precursors of postmandibular appendages developed on both lateral sides. Anterior two unarmed limb-buds are assumed to represent maxillule and maxilliped precursors. First two swimming legs (legs 1-2) indicated at the sixth naupliar stage. Lobe with 2 small setae corresponding to leg one, and further caudally, lobe with 2 setae corresponding to leg two (Fig. 16).

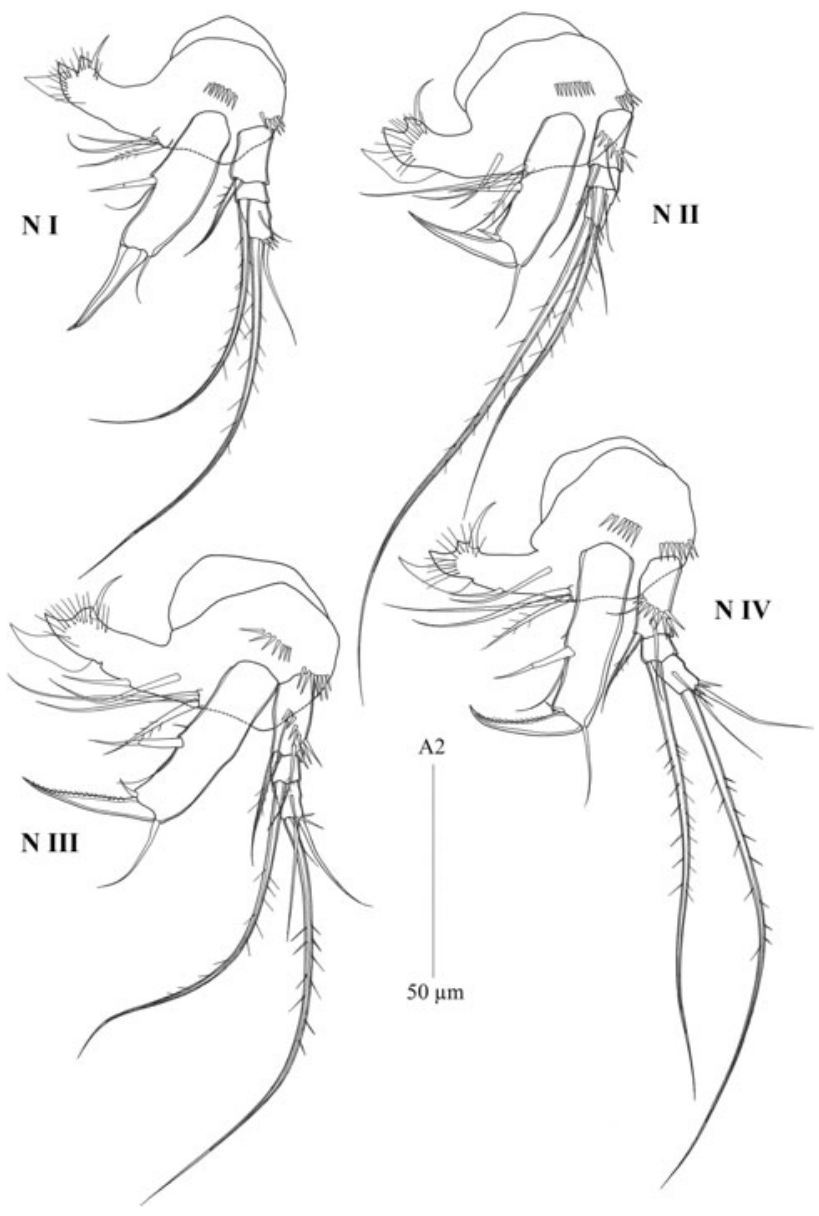

Fig. 18 Tigriopus thailandensis sp. nov. Development of the naupliar left antennae of naupliar stages I to IV in anterior view. sp. nov

Biological remarks. Individuals of all six naupliar stages are able to crawl and to swim-crawl on surfaces. All developmental stages including nauplii can also swim freely in the water column, and aggregate to swarms in their splash-pool habitat.

\section{Discussion}

Tigriopus thailandensis sp. nov. shares with its closest relative, T. japonicus Mori 1932, the two inner setae on the third exopodal segment of leg 4, while other congeners bear three inner setae. Allobasis and exopod of antenna are much more slender and elongate in $T$. thailandensis than in T. japonicus. There are nine spinule patches on the female antenna of $T$. thailandensis, whereas there are only two in $T$. japonicus. In both genders of $T$. thailandensis, the third exopodal segment of leg 1 bears five claw-like setae, with the outermost slender, whereas in $T$. japonicus it bears three setae, with the outermost being very stout. The first endopodal segment of leg 1 bears strong spiniform spinules 


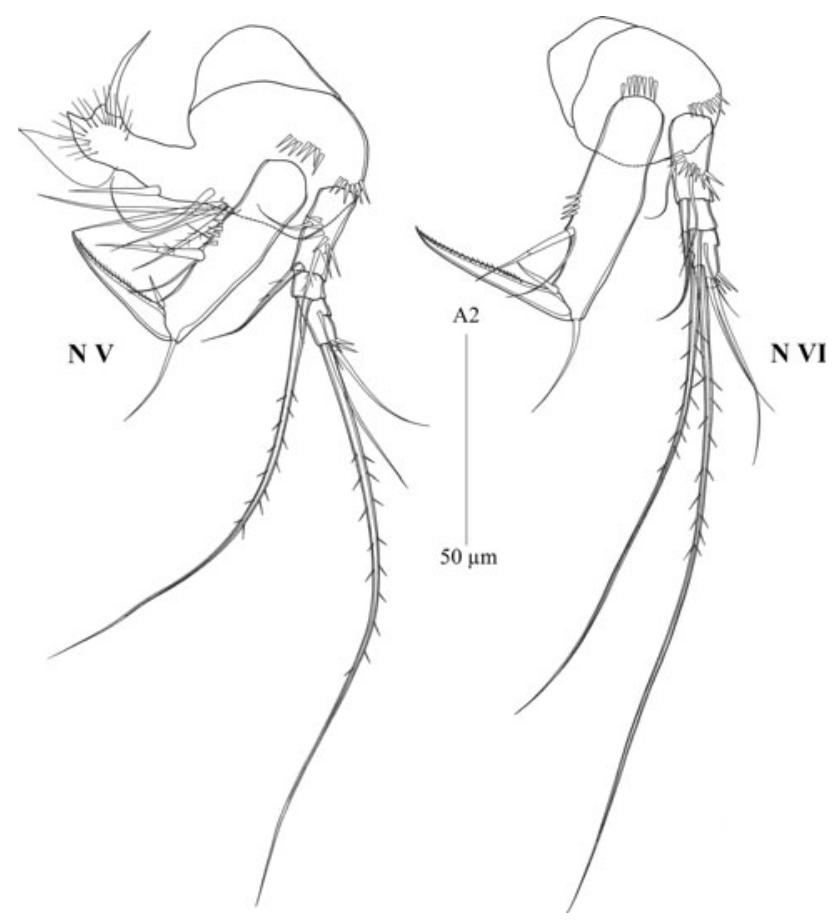

Fig. 19 Tigriopus thailandensis sp. nov. Development of the naupliar left antennae of naupliar stages V to VI in anterior view. Antenna of fifth to sixth naupliar stage abbreviated as N V to N VI, respectively

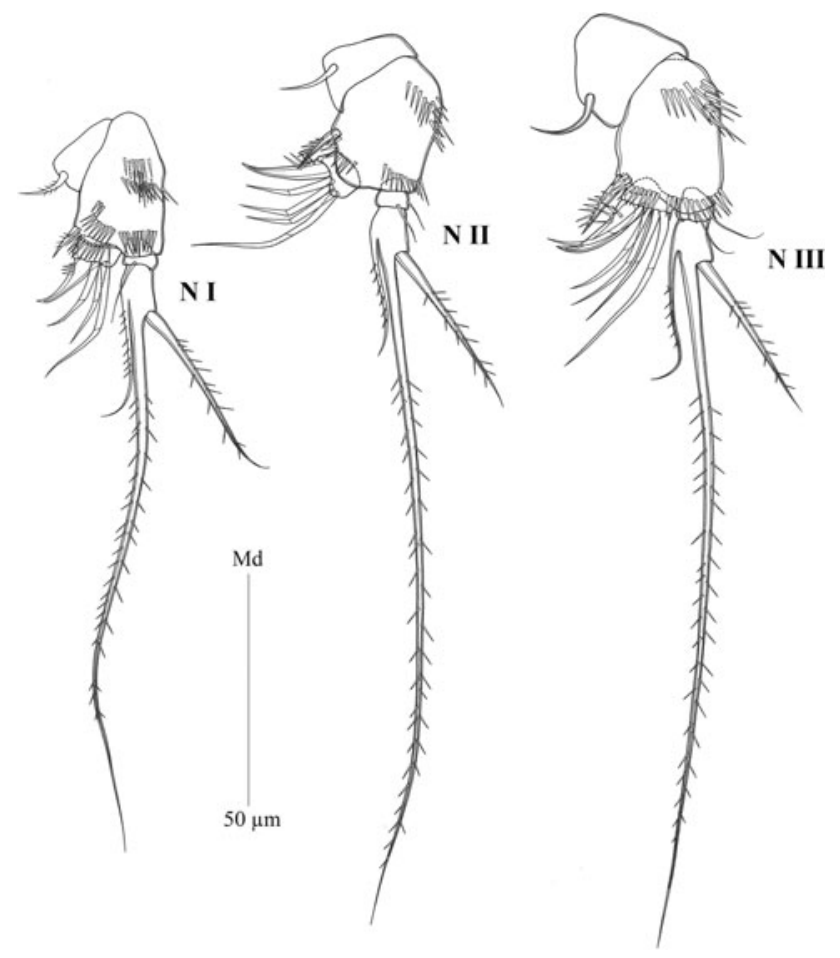

Fig. 20 Tigriopus thailandensis sp. nov. Development of the naupliar left mandibles of naupliar stages I to III in anterior view. Mandible of first to third naupliar stage abbreviated as N V to N VI, respectively

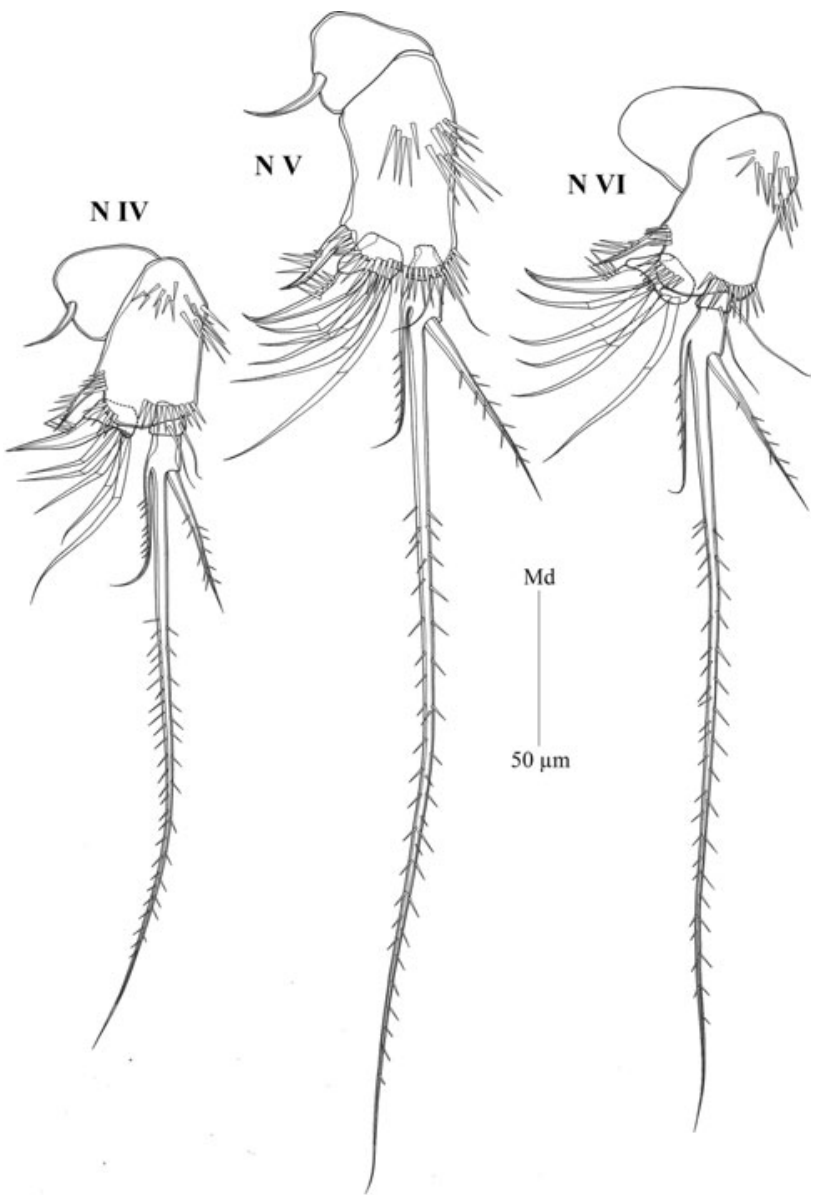

Fig. 21 Tigriopus thailandensis sp. nov. Development of the naupliar left mandibles of naupliar stages IV to VI in anterior view. Mandible of fourth to sixth naupliar stage abbreviated as $\mathrm{N} \mathrm{V}$ to $\mathrm{N}$ VI, respectively

along its distal rim in T. thailandensis, whereas there are only tiny spinules in $T$. japonicus. The lobe of leg 6 is pronounced, twice as wide as long, and the outer seta is oriented outwardly in $T$. thailandensis, whereas all three setae are directed caudally in $T$. japonicus.

Besides the present new species from Thailand, the following species of Tigriopus are known so far: T. brevicornis from northern Europe, T. fulvus (Fischer 1860) from the Adriatic, T. californicus from North America, T. angulatus from New Zealand, T. brachydactylus Candeias, 1959, and T. minutus Bozic 1960 from Europe. Tigriopus japonicus was described by Mori (1932) from Shimoda (Japan), and the species has been redescribed by Itô (1970) from Hokkaido (Japan). T. raki was described by Bradford (1967) from New Zealand; T. igai from Bonin Islands, Japan (Itô 1977); T. kerguelensis and T. crozettensis from the South Indian Ocean (Soyer et al. 1987). Lang (1948) treated T. fulvus as synonymous with T. brevicornis. However, Bozic (1960) recognized them as distinct species. T. minutus is similar to T. brachydactylus, 
particularly in the female setal armature of P5. The lack of an outer seta on the exp 2 of leg 1 in $T$. brachydactylus seems to be an artifact, since all other Tigriopus species show this seta.

As in most Harpacticoida, postmandibular appendages of naupliar stages show a great variation in both $T$. thailandensis and T. japonicus: from their first appearance, in the total number present at N VI, and in their shape and armature. At N VI, the first maxilla, second maxilla, maxilliped, legs one and two may all be present, and they can then be identified according to their position from front to rear.

\section{Naupliar development in the Harpacticidae}

Itô (1970) and Koga (1970) examined Japanese populations of T. japonicus. The study of Itô (1970) is lacking the N IV. In particular, Koga (1970) documents the first maxilla from N III onwards, whereas it is expressed in Ito's and the present account of $T$. thailandensis sp. nov. as early as at the N II stage.

According to Walker (1981), segmentation is lacking on both the antennal and mandibular exopod in Harpacticus sp. throughout the phase. This is in contrast to the present observation of a four-segmented antennal and a two-segmented mandibular exopod in T. thailandensis as well as in T. japonicus from a Taiwan population (Dahms et al. 2007). These characters in T. thailandensis have also been confirmed in another harpacticid genus Harpacticus by Castel (1976) for H. littoralis. Clogston (1965) described the antennal exopod of Zaus spinatus as being 2-segmented throughout the phase, whereas it is four-segmented in $T$. thailandensis and T. japonicus. In contrast to the present report on T. thailandensis, Clogston (1965) argued that there was no indication of the first maxilla in $Z$. spinatus.

Tigriopus thailandensis sp. nov. lacks armature on the first segment of the antennule throughout the nauplius phase, whereas one seta is present in $T$. japonicus according to Dahms et al. (2007). There are three long setae in $T$. japonicus on the antennule's second segment whereas only one small seta plus two longer setae develop in $T$. thailandensis sp. nov.

There is an aesthetasc on the antennule's third segment in T. thailandensis sp. nov. that is not discernible on the third segment in T. japonicus. There is one seta more on the third segment in T. thailandensis sp. nov. than in T. japonicus (that means: seven setae plus one aesthetasc at N III versus six setae, plus one aesthetasc) until both reach thirteen setae, plus one aesthetasc at N VI in both species. There are no spinules on this terminal segment in $T$. japonicus, whereas there are spinules from N II onwards in $T$. thailandensis sp. nov. The second antenna of $T$. thailandensis sp. nov. bears 3 small spinules on the terminal segment of the exopod, whereas there are no in T. japonicus. In $T$. thailandensis sp. nov. there is one additional seta on the anterior surface of the basis. The tubular endopod bears a tiny seta midlength at N III that increases in size throughout the naupliar development. The mandibular coxal seta bears one spinulose seta in $T$. thailandensis sp. nov. that is smooth in T. japonicus. Several spinules are present on the anterior surface of the basis of T. thailandensis sp. nov., whereas there is only one row in T. japonicus.

Acknowledgments This research is supported by the National Research Council of Thailand (Grant 2551A1120211) and Ramkhamhaeng University. The work of V. N. Ivanenko is supported by the Russian Foundation for Basic Research (Grant 06-04-48918-a). The work of W.-X. Yang is supported by the National Nature Science Foundation of China (Grant 31072198 and 40776079).

\section{References}

Alekseev VR (2002) Copepoda. In: Fernando CH et al (eds) A guide to tropical freshwater zooplankton-identification, ecology and impact on fisheries. Backhuys Publishers, Leiden, pp 123-188

Bozic B (1960) Le genre Tigriopus Norman (Copépodes Harpacticoïdes) et ses formes européennes; recherches morphologiques et expérimentales. Arch Zool Exp Gén 98(3):167-269

Bradford J (1967) The genus Tigriopus Norman (Copepoda, Harpacticoida) in New Zealand with a description of a new species. Trans Roy Soc NZ Zool 10(6):51-59

Burton RS, Rawson PD, Edmands S (1999) Genetic architecture of physiological phenotypes: empirical evidence for coadapted gene complexes. Am Zool 39:451-462

Castel J (1976) Développement larvaire et biologie de Harpacticus littoralis Sars, 1910 (copépode, harpacticoide) dans les étangs saumâtres de la région d'Arcachon. Cah Biol Mar 17:195-212

Clogston F (1965) Postembryonic development of species of harpacticoid copepods from the Pacific coast of the United States and an application of developmental patterns to their systematics. $\mathrm{PhD}$ dissertation, Univ. of Washington, Seattle, $246 \mathrm{pp}$

Dahms H-U (1990) Naupliar development of Harpacticoida (Crustacea, Copepoda) and its significance for phylogenetic systematics. Mikrof Mar 6:169-272

Dahms H-U (1993) Pictorial keys for the identification of crustacean nauplii from the marine meiobenthos. J Crust Biol 13:609-616

Dahms H-U, Fornshell JA, Fornshell BJ (2006) Key for the identification of crustacean nauplii. Org Divers Evol 6:47-56

Dahms H-U, Chullasorn S, Kangtia P, Ferrari FD, Hwang J-S (2007) Naupliar development of Tigriopus japonicus Mori, 1932 (Harpacticidae, Copepoda). Zool Stud 46:746-759

Davenport J, Barnett PRO, McAllen RJ (1997) Environmental tolerances of three species of the harpacticoid genus Tigriopus. J Mar Biol Assoc UK 77:3-16

Dethier MN (1980) Tidepools as refuges: predation and the limits of the harpacticoid copepod Tigriopus californicus. J Exp Mar Biol Ecol 42:99-111

Edmands S (1999) Heterosis and outbreeding depression in interpopulation crosses spanning a wide range of divergence. Evolution 53:1757-1768

Edmands S, Burton RS (1998) Variation in cytochrome-c oxidase activity is not maternally inherited in the copepod Tigriopus californicus. Heredity (Lond) 80:668-674 
Fraser JH (1936) The occurrence, ecology and life history of Tigriopus fulvus (Fischer). J Mar Biol Assoc UK 20:523-536

Guiglia D (1926) Sullo sviluppo larvale de Tigriopus fulvus (Fischer). Boll Mus Zool Anat Comp R Univ Gen (2)6(3):11-16

Igarashi S (1963) Developmental cycle of Tigriopus japonicus Mori. Sci Rep Tohoku Univ 29(2):59-72

Itô T (1970) The biology of a harpacticoid copepod Tigriopus japonicus Mori. J Fac Sci, Hokkaido Univ, Ser VI, Zool 17:474-500

Itô T (1973) Ventral nerve cord of Tigriopus japonicus Mori (Copepoda, Harpacticoida). Annot Zool Japon 46(1):45-48

Itô T (1977) New species of marine harpacticoid copepods of the genera Harpacticella and Tigriopus from the Bonin Islands, with reference to the morphology of copepodid stages. J Fac Sci Hokkaido Univ Ser VI Zool 32:273-326

Ivanenko VN, Ferrari FD, Dahms H-U (2008) Nauplii of Tegastes falcatus (Norman, 1868)(Harpacticoida, Tegastidae), a copepod with an unusual naupliar mouth and mandible. J Crust Biol 28:270-280

Jung SO, Lee YM, Park TJ, Park HG, Leung KMY, Dahms H-U, Lee W, Lee JS (2006) The complete mitochondrial genome of the intertidal copepod Tigriopus sp. (Copepoda, Harpacticidae) from Korea and phylogenetic considerations. J Exp Mar Biol Ecol 333:251-262

Kelly LS, Snell TW (1998) Role of surface glycoproteins in mate guarding of the marine harpacticoid Tigriopus japonicus. Mar Biol 130:605-612

Kim IC, Kim YJ, Song SJ, Lee J-S, Lee W (2003) The intertidal harpacticoid copepod Tigriopus japonicus (Crustacea: Copepoda) $\beta$-actin gene: cloning, sequence and intraspecies variation. DNA Seq 14:279-284

Kim IC, Kim YJ, Lee Y-M, Kim BG, Park TJ, Kim HS, Jung MM, Williams TD, Lee W, Lee J-S (2004) cDNA cloning of translationally controlled tumor protein/histamine releasing factor (TCTP/HRF) from the intertidal harpacticoid copepod Tigriopus japonicus. DNA Seq 15:159-163

Koga F (1970) On the life history of Tigriopus japonicus Mori (Copepoda). J Oceanogr Soc Japan 26(1):11-21

Lang K (1948) Monographie der Harpacticiden I, II. Reprint Otto Koeltz Science Publ, Königstein 1682 p

Lee JS (2003) cDNA cloning of rhoA gene from the intertidal harpacticoid copepod Tigriopus japonicus (Crustacea, Copepoda). Kor J Gen 25:403-408
Lee YM, Kim IC, Jung SO, Lee JS (2005) Analysis of 686 expressed sequence tags (ESTs) from the intertidal harpacticoid copepod Tigriopus japonicus (Crustacea, Copepoda). Mar Poll Bull 51:757-768

Machida RJ, Miya MU, Nishida M, Nishida S (2002) Complete mitochondrial DNA sequence of Tigriopus japonicus (Crustacea: Copepoda). Mar Biotechnol 4:406-417

McAllen R (1998) Life at its limits-the ecophysiology of the high shore rockpool inhabitant Tigriopus brevicornis. $\mathrm{PhD}$ thesis, University of London

McAllen R (1999) Enteromorpha intestinalis-a refuge for the supralittoral rockpool harpacticoid copepod Tigriopus brevicornis. J Mar Biol Assoc UK 79:1125-1126

McAllen R, Block W (1997) Aspects of the cryobiology of the intertidal harpacticoid copepod Tigriopus brevicornis. Cryobiology 35:309-317

McAllen R, Taylor AC, Davenport J (1998) Osmotic and body density response in the harpacticoid copepod Tigriopus brevicornis in supralittoral rockpools. J Mar Biol Assoc UK 78:1143-1153

Mori T (1932) Tigriopus japonicus, a new species of neritic Copepoda. Zool Mag Tokyo 50(5):294-295

Raisuddin S, Kwok KWH, Leung KMY, Schlenk D, Lee J-S (2007) The copepod Tigriopus: A promising marine model organism for ecotoxicology and environmental genomics. Aquat Tox 83:161-173

Shaw TH (1938) Some observations on the life history of a tide-pool copepod, Tigriopus fulvus (Fischer). Bull Fan Mem Inst Biol Zool 8:9-17

Soyer J, Thiriot-Quievreux C, Colomines JC (1987) Description de deux espèces jumelles du groupe Tigriopus angulatus (Copepoda, Harpacticoida) dans les archipels Crozet et Kerguelen (Terres Australes et Antarctiques Françaises). Zool Scr 16(2):143-154

Walker X (1981) Reproductive biology and development of a marine harpacticoid copepod reared in the laboratory. J Crust Biol $1: 376-388$

Wells BJ (2007) An annotated checklist and keys to the species of Copepoda Harpacticoida (Crustacea). Zootaxa 1568:872 